Floresta e Ambiente 2021; 28(4): e20200090

https://doi.org/10.1590/2179-8087-FLORAM-2020-0090

ISSN 2179-8087 (online)

ORIGINAL ARTICLE - Forest Products Science and Tecnology

Floresta e Ambiente

\title{
Use of Populus deltoides wood in the Production of MDP and HDP
}

\author{
Pâmela Caroline Lau Sozim ${ }^{1}$ (D) \\ Everton Hillig ${ }^{2}$ (D) \\ Raquel Marchesan ${ }^{3}$ \\ Fabiane Salles Ferro ${ }^{2}$ (D) \\ ${ }^{1}$ Universidade Estadual do Centro-Oeste, Programa de Pós-Graduação em Ciências Florestais, Irati, PR, Brasil. \\ ${ }^{2}$ Universidade Estadual do Centro-Oeste, Departamento de Engenharia Florestal, Irati, PR, Brasil. \\ ${ }^{3}$ Universidade Federal do Tocantins, Departamento de Engenharia Florestal, Gurupi, TO, Brasil.
}

\begin{abstract}
The aimed to evaluate the properties of MDP and HDP panels, produced with pure Populus deltoides or in a mixture with Pinus taeda, together with urea-formaldehyde resin. The density and chemical properties of this wood with 8 and 12 years of age were determined, which were used for the production of panels with nominal density of 0.65 and $0.90 \mathrm{~g} . \mathrm{cm}^{-3}$. Water absorption and thickness swelling tests were performed after 2 and 24 hours of immersion, as well as static bending and perpendicular tensile. Populus deltoides wood was classified as low-density in both ages and presented chemical properties similar to Pinus taeda. Mechanical properties obtained for the panels produced reached the minimum requirements values established by the standards NBR 14810-2 and ANSI A208.1, demonstrating the potential use of wood species for the production of MDP and HDP panels, at both ages studied and used pure or mixed with Pinus taeda wood.
\end{abstract}

Keywords: Poplar, Pinus taeda, Chemical properties, Panels, Physical-mechanical properties.

\section{INTRODUCTION AND OBJECTIVES}

For particleboard production, companies use Pinus taeda, Eucalyptus grandis and Eucalyptus urograndis species as raw material, which the plantations are located mainly in the south of the country. For this purpose, the trees are cut shallowly at age of 15 for pine and close to 7 for eucalyptus (Arauco Forest Brasil SA, 2018; Berneck SA, 2019).

The high demand and competitiveness for these wood species in order to make other types of panels, such as fiberboard and plywood, in addition to sawn wood, create the need to increase planting areas or seek alternative species of fast growth (Trianoski et al., 2017). According to Trianoski et al. (2011) and Bianche et al. (2012), the use of new species, pure or mixed with traditional species, in the production of particleboard is characterized as a fast, low cost, and sustainable alternative.

In Brazil, several alternative species for the production of particleboard have already been researched, such as Schizolobium amazonicum and Cecropia hololeuca (Iwakiri et al., 2010); Cryptomeria japonica (Trianoski et al., 2013); Toona ciliata (Trianoski et al., 2014); Hovenia dulcis and Mimosa scabrella (Sanches et al., 2016); Pinus patula (Rios et al., 2016); Eucalyptus badjensis (Pereira et al., 2017); Hevea brasiliensis (Iwakiri et al., 2018); Ligustrum lucidum (Sozim et al., 2019); Cupressus torulosa (Iwakiri et al., 2020).

According to the Forest Stewardship Council (FSC, 2020), in countries as China, Slovenia, Taiwan, Austria, Poland, India, and Spain, there are records of the use of Populus deltoides wood for particleboard production. Populus deltoides is a fast-growing species naturally occurring in the United States and Canada. In Brazil, they have been cultivated in the states of Paraná and Santa Catarina, aiming mainly at making matchsticks (Medeiros \& Hope, 2002; Lorenzi et al., 2003).

The Populus genus has a wide variety of species, which highlight for their rapid growth, chemical composition (absence of resins), whitish color, straight fiber, hybridization potential, ease of regrowth and adaptation to different edaphoclimatic conditions (Medeiros \& Hope, 2002; Arce, 2004; Kuzovkina \& Vietto, 2014). 
For Mercosul countries, Populus spp. has a great economic importance, especially in Argentina, where it is the third most planted forest genus (SBS, 2006). In Argentina and in the vast majority of plantations worldwide, the species Populus nigra L. and Populus deltoides W. Bartram ex Marshall and their hybrids ( $P$. nigra $\times$ P. deltoides) are cultivated (Borodowski, 2006).

Lau (2017) and Javarini (2011) studied Populus deltoides wood at 12 and 11 years old in Santa Catarina, and reported that it was a low density wood $\left(0.33 \mathrm{~g} . \mathrm{cm}^{-3}\right)$ with potential for making edge glued panels (EGP), particleboard, and plywood. Nourbakhsh (2010) assessed the technical feasibility of producing particleboard with Populus deltoides wood for a 3 -year-old planting grown in Iran. The author reported that the panels had adequate physical and mechanical properties for non-structural application as interior decoration (furniture, walls, and ceiling panels), demonstrating the possibility of using this species in the first years of planting.

The age of the tree is an extremely important factor when it comes to the end use of wood, as several transformations in the anatomical and chemical composition, as well as physical and mechanical characteristics occur as it ages, interfering in the quality of the wood and consequently in the age of cutting (Vidaurre et al., 2012; Carneiro et al., 2014; Soares et al., 2015).

Regarding this scenario, this study aimed to evaluate the quality of homogeneous particleboards, with medium and high density, produced with pure Populus deltoides wood or mixed with Pinus taeda, together with the urea-formaldehyde resin.

\section{MATERIALS AND METHODS}

The commercial plantations of Populus deltoides with 8 and 12 years old, located in the cities of Porto União and Irineópolis, both located in Santa Catarina state, were implanted by means of cuttings with approximately $4.5 \mathrm{~m}$ in length and $5 \mathrm{~cm}$ in diameter at breast height (DBH). It was used the spacing of $5.2 \mathrm{m \times} 6 \mathrm{~m}$, and silviculture methods as fertilizing, weed control, disease and pest control, and pruning were adopted.

For the study, three Populus deltoides trees were ramdomly selected by age. Trees were harvested, delimbed, and sectioned in $25 \%, 50 \%, 75 \%$, and $100 \%$ of commercial height. It was adopted as a tip diameter of $16 \mathrm{~cm}$, the last log being used to make medium density particleboard (MDP) and highdensity particleboard (HDP).

The basic density of the wood was determined according to the recommendations of the NBR 11941 standards (ABNT, 2003 ), thus, at $75 \%$ and $100 \%$ of the commercial height, a $5 \mathrm{~cm}$ thick disk was removed. For the determination of chemical properties, which consisted of extracts in cold water, extracts in hot water, extracts in sodium hydroxide, extracts in ethanol-toluene, insoluble lignin, ash and pH, TAPPI 207 standards (TAPPI, 1999), TAPPI 212 (TAPPI, 2002), TAPPI 204 (TAPPI, 1997), TAPPI 222 (TAPPI, 2002), TAPPI 252 (TAPPI, 2002), TAPPI 211 (TAPPI, 2002) and NBR 14853 (ABNT, 2002), respectively, in a sample taken from the disc corresponding to $25 \%$ of the commercial height.

The logs of Populus deltoides were unfolded on a band saw and processed in a disc chipper and forage chipper/shredder, until obtaining "sliver" particles. Pinus taeda wood with a bulk density of $0.41 \mathrm{~g} . \mathrm{cm}^{-3}$ in the form of particles, as well as resin, catalyst and paraffin, were obtained in a particleboard industry in the region of Guarapuava-PR, Brazil. For adhesion of the particles, urea-formaldehyde resin was used in the proportion of $10 \%$ solids in relation to the dry weight of the particles, with the following properties: $66.5 \%$ solids content, $8.2 \mathrm{pH}, 324 \mathrm{cPs}$ of Brookfield viscosity, $40 \mathrm{~s}$ of gel time, and

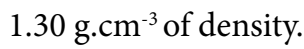

Paraffin of $1 \%$ was used to reduce the hygroscopicity of the panels either, and $2 \%$ ammonium sulfate as a catalyst to accelerate the curing time of the resin. For the agglutination of the panels, a specific pressure of $40 \mathrm{Kgf.cm}^{-2}$, a temperature of $160^{\circ} \mathrm{C}$, and a pressing time of 10 minutes were used. Homogeneous panels were produced with five combinations of wood and two densities, totaling 10 types of panels with three repetitions each (Table 1).

Table 1. Composition of the MDP and HDP panels.

\begin{tabular}{ccc} 
Panel & Wood & Density $\left(\mathbf{g} \cdot \mathrm{cm}^{-3}\right)$ \\
\hline 1 & $100 \% \mathrm{Pt}$ & 0.65 \\
2 & $100 \% \mathrm{Pd} 8$ & 0.65 \\
3 & $50 \% \mathrm{Pt}+50 \% \mathrm{Pd} 8$ & 0.65 \\
4 & $100 \% \mathrm{Pd} 12$ & 0.65 \\
5 & $50 \% \mathrm{Pt}+50 \% \mathrm{Pd} 12$ & 0.65 \\
6 & $100 \% \mathrm{Pt}$ & 0.90 \\
7 & $100 \% \mathrm{Pd} 8$ & 0.90 \\
8 & $50 \% \mathrm{Pt}+50 \% \mathrm{Pd} 8$ & 0.90 \\
9 & $100 \% \mathrm{Pd} 12$ & 0.90 \\
10 & $50 \% \mathrm{Pt}+50 \% \mathrm{Pd} 12$ & 0.90
\end{tabular}

Legend: $\mathrm{Pt}$ - Pinus taeda; $\mathrm{Pd} 8$ - Populus deltoides 8 years; Pd12 - Populus deltoides 12 years.

After pressing, the panels remained in an air-conditioned chamber with a relative humidity of $65 \pm 5 \%$, and a temperature of $20 \pm 3^{\circ} \mathrm{C}$ until they reached the equilibrium moisture content. After this period, it were obtained specimens for physical properties determination as water absorption and thickness swelling after 2 and 24 hours of immersion in water (WA2; WA24; TS2; TS24). Mechanical properties as static bending, to determine the modulus of elasticity (MOE) and modulus of rupture (MOR), and tensile strength perpendicular 
to the panel surface to check the internal bond (IB) were also determined. These test were performed according to recommendations of NBR 14810-2 standard (ABNT, 2013). From each produced panel, 10 specimens were obtained for physical and mechanical test. The compaction ratio of the panels was also determined using values density and composition density of the panel, as described by Moslemi (1974).

Particle geometry of Populus deltoids at 8 and 12 years old, and of Pinus taeda obtained from the industry, was evaluated using the slenderness ratio, the flatness ratio, and the surface area as described by Moslemi (1974). A sample of 100 particles was used for each species.

To verify difference in physical and chemical characteristics of the wood, values were compared by means of a completely randomized design, which was considering as treatments the species Populus deltoides -8 year and Populus deltoides -12 years old. It were considered 3 repetitions for chemical properties and 6 repetitions for physical properties. For particle geometry, values obtained were compared using a completely randomized design considering as treatments Pinus taeda, Populus deltoides species -8 years old and Populus deltoides - 12 years old, with 100 repetitions. For compaction ratio values and for those obtained in the physical and mechanical tests for MDP and HDP panels, the comparison was made through a completely randomized design considering the five wood combinations (100\% Pt; $100 \%$ Pd8 ; 50\% Pt + $50 \% \mathrm{Pd} 8 ; 100 \% \mathrm{Pd} 12 ; 50 \% \mathrm{Pt}+50 \% \mathrm{Pd} 12)$ as treatments. It were considered 10 repetitions for each property analyzed.

Thus, the values obtained for the physical and chemical properties of wood, particle geometry, compaction ratio and physical and mechanical properties of MDP and HDP panels were subjected to statistical tests. Kolmogorov-Smirnov test were used to analyze the normality of the data; Levene's test to analyze the homogeneity of variances. Once the normality and homogeneity of the variances was confirmed, the Analysis of Variance (ANOVA) was applied. If the equality hypothesis was rejected by ANOVA, the averages were compared using Tukey test at of 5\% significance level. Pearson's correlation analysis was also performed between the average values obtained for the physical and mechanical properties of the MDP and HDP panels.

\section{RESULTS AND DISCUSSION}

\subsection{Wood properties}

Table 2 shows the average values of basic density, extracts in cold water, extracts in hot water, extracts in sodium hydroxide, extracts in ethanol-toluene, insoluble lignin, ash and $\mathrm{pH}$. With the exception of the basic density and the content of extractives in sodium hydroxide, for the other chemical properties analyzed, significant statistical differences were found where higher values were obtained with increasing age of Populus deltoides wood.

The increase in the extractives levels according to the age of tree, soluble in water and/or organic solvent may be attributed to the process of wood cernification (Soares et al., 2015; Fonte et al., 2017). Already the increase in ash content with the age may be linked to the influence of habitat and the fertilization received by trees. The presence of higher values of non-process minerals in wood could affects the quality of its by-products, such as charcoal and paper, in addition to being able to compromise the performance of machinery due to its wear by this component (Garcia et al., 2016; Benites et al., 2018).

Table 2. Average values of the physicochemical properties of Populus deltoides wood at 8 and 12 years of age.

\begin{tabular}{|lcc|}
\multirow{2}{*}{\multicolumn{1}{c}{ Property }} & \multicolumn{2}{c|}{ Populus deltoides } \\
\cline { 2 - 3 } & 8 years & 12 years \\
\hline Basic density $\left(\mathrm{g.cm}^{-3}\right)$ & $0.38 \mathrm{a}(7.47)$ & $0.40 \mathrm{a}(4.53)$ \\
\hline Extracts in cold water (\%) & $1.63 \mathrm{~b}(9.87)$ & $2.03 \mathrm{a}(7.74)$ \\
\hline Extracts in hot water (\%) & $1.87 \mathrm{~b}(15.34)$ & $2.46 \mathrm{a}(3.86)$ \\
\hline Extracts in sodium hydroxide (\%) & $15.35 \mathrm{a}(1.13)$ & $15.51 \mathrm{a}(1.69)$ \\
\hline Extracts in ethanol-toluene (\%) & $1.24 \mathrm{~b}(20.97)$ & $1.77 \mathrm{a}(1.63)$ \\
\hline Insoluble lignin (\%) & $27.80 \mathrm{~b}(1.28)$ & $30.02 \mathrm{a}(1.07)$ \\
\hline Ash (\%) & $0.81 \mathrm{~b}(8.06)$ & $1.07 \mathrm{a}(9.60)$ \\
\hline $\mathrm{pH}$ & $5.88 \mathrm{~b}(2.58)$ & $6.26 \mathrm{a}(1.26)$ \\
\hline
\end{tabular}

Legend: averages followed by the same letter on the line do not differ by the Tukey test at $5 \%$ significance level; value in parentheses refers to the percentage variation coefficient.

For basic density, average values of $0.38 \mathrm{~g} . \mathrm{cm}^{-3}$ were obtained for wood from trees with age of 8 years and $0.40 \mathrm{~g}^{\mathrm{cm}} \mathrm{cm}^{-3}$ of 12 years old. Results obtained in this study are compatible with $0.38 \mathrm{~g} . \mathrm{cm}^{-3}$ of basic density reported by Klasnja et al. (2003) for Populus deltoides clones wood of 4 year.

Basic density obtained for Populus deltoides woods at the ages of 8 and 12 years, is close to $0.48 \mathrm{~g} . \mathrm{cm}^{-3}$ found by Trianoski et al. (2016) for Pinus taeda wood, a species traditionally used in particleboard manufacture in Brazil.

Low density of Populus deltoides wood in both ages, indicate ease of bonding of wood. That characteristic are associated with wood with thin - walled cells and with large lumens. Thus, consequently, a greater amount of resin may be absorved, thus not requiring the application of high pressure during the pressing process (Frihart \& Hunt, 2010). Moslemi (1974) adds that besides to the influence on gluing, the use of low-density wood in the production of particleboard leads to obtaining adequate values for compaction ratio.

Results obtained in this study for extracts in ethanol-toluene, insoluble lignin and ash are in line with those reported by Klasnja 
et al. (2003) and Jin \& Kamdem (2009) when studying Populus wood. Klasnja et al. (2003) obtained the content of $22.20 \%$ insoluble lignin and $2.20 \%$ of extracts in ethanol-toluene for the wood of clones of Populus deltoides with 4 years of age. Jin \& Kamdem (2009) found the contents of $22.55 \%$ insoluble lignin, $4.00 \%$ extracts in ethanol-toluene and $0.69 \%$ ash for the wood of the hybrid Populus deltoides x Populus nigra var. Caudina.

The levels of extracts soluble in cold water, hot water, $\mathrm{NaOH}$ and ethanol-toluene, as well as the results obtained for insoluble lignin, ash and $\mathrm{pH}$ obtained for the wood of Populus deltoides in the three ages under study, are close to those presented by Lau (2017) for the wood of Populus deltoides at 11 years. The author obtained an average of $2.62 \%$ for extracts in cold water, $3.39 \%$ for extracts in hot water, $17.74 \%$ for extracts in $\mathrm{NaOH}$, 2.45\% for extracts in ethanol-toluene, $27.01 \%$ for insoluble lignin, $0.98 \%$ for ash and 6.72 for $\mathrm{pH}$.

The values of $3.14 \%$ of total extracts, $27.67 \%$ of lignin and 4.56 of pH obtained by Iwakiri et al. (2017) and Pereira et al. (2017) for Pinus spp. industrial particles are close to the average values found for Populus deltoides woods, demonstrating the potential of the species under study as a raw material for the particleboards production.

\subsection{Particle geometry}

For the characteristics, slenderness ratio, flatness ratio, and surface area determined for Pinus taeda and Populus deltoides particles 8 and 12 years shown in Table 3 , a statistical difference was found. The difference, mainly between species, may be attributed to the equipment used for particles generation. Particles from Pinus taeda used in this study were produced on an industrial level using automated equipment, while particles from Populus deltoides were obtained using less sophisticated equipment, besides that its classification being performed manually with the aid of sieves.

Table 3. Average values of the characteristics of the particles of Pinus taeda and Populus deltoides.

\begin{tabular}{lccc}
\multicolumn{1}{c}{ Species } & $\begin{array}{c}\text { Slenderness } \\
\text { ratio }\end{array}$ & $\begin{array}{c}\text { Flatness } \\
\text { ratio }\end{array}$ & $\begin{array}{c}\text { Surface area } \\
\left(\mathrm{cm}^{-2} / \mathrm{g}\right)\end{array}$ \\
\hline Pinus taeda & $13.63 \mathrm{a}$ & $2.12 \mathrm{a}$ & $67.39 \mathrm{c}$ \\
& $(16.33)$ & $(27.03)$ & $(14.74)$ \\
Populus & $6.27 \mathrm{~b}$ & $1.83 \mathrm{~b}$ & $77.46 \mathrm{~b}$ \\
deltoides - 8 years & $(30.10)$ & $(25.69)$ & $(12.58)$ \\
Populus & $6.36 \mathrm{~b}$ & $1.78 \mathrm{~b}$ & $83.53 \mathrm{a}$ \\
deltoides - 12 years & $(32.84)$ & $(37.23)$ & $(10.36)$ \\
\hline
\end{tabular}

Legend: averages followed by the same letter in the column do not differ by Tukey test at $5 \%$ probability of error; value in parentheses refers to the percentage variation coefficient.

The long, fine particles of Pinus taeda led to a higher rate of slenderness and flatness ratio and a smaller surface area, tending to obtain panels with greater strength to static bending and greater dimensional stability. In contrast, the shorter and thicker particles obtained for Populus deltoides with 8 and 12 years provided a greater surface area and lower slimness ratio and flatness ratio. Consequently, panels produced with these type of particles presented a greater of availability of resin, which may provided improvement in tensile strength perpendicular due to its more efficient bonding (Vital et al., 1992).

\subsection{Physical and mechanical properties of MDP and HDP panels}

MDP panels presented density close to the established nominal density of $0.65 \mathrm{~g} . \mathrm{cm}^{-3}$, classified, according to the ANSI A208.1 standard (ANSI, 2009), as medium density $\left(0.64 \mathrm{~g} . \mathrm{cm}^{-3}\right.$ to $\left.0.8 \mathrm{~g} . \mathrm{cm}^{-3}\right)$ (Table 4$)$. The average values of compaction ratio ranged from 1.54 to 1.67 , considering the range from 1.3 to 1.6, reported by Moslemi (1974) as ideal for particleboard.

A statistical difference was found between the studied properties, highlighting that the addition of Populus deltoides wood in the composition with Pinus taeda provided an improvement in the dimensional stability of the panels.

For MOR, MOE, and IB (Table 4), a reduction in average values was found when Pinus taeda was mixed with Populus deltoides at both ages. In general, it appears that the panels produced with the wood of Populus deltoides at the age of 8 resulted in better physical-mechanical properties.

Regarding the fulfillment of the minimum requirements required by NBR 14810-2 (ABNT, 2013) for non-structural panels intended for indoor use in dry conditions, none of the panels manufactured met the maximum requirement of $18 \%$ thickness swelling after 24 hours immersion. Better results may be obtained with the increase in the proportion of urea-formaldehyde resin in the production of the panels. As far as the mechanical properties are concerned, all of them met the minimum values of $11 \mathrm{MPa}, 1800 \mathrm{MPa}$, and $0.40 \mathrm{MPa}$ for MOR, MOE, and IB, respectively, required by the standard mentioned.

Values of this study and those reported in the literature were compared Hafezi et al. (2015) evaluated medium density particleboards $\left(0.70 \mathrm{~g} . \mathrm{cm}^{-3}\right)$ manufactured in the proportion of 55/45, with wheat straw (Triticum aestivum L.) and populus (Populus sp.) wood whole shafts and ureaformaldehyde resin. Authors found for the mechanical properties meas values of $7 \mathrm{MPa}, 1000 \mathrm{MPa}$, and $0.1 \mathrm{MPa}$ for MOR, MOE, and IB, respectively. For physical properties of water absorption and thickness swelling after 2 and 24 hours of immersion, the values obtained were $105 \%, 125 \%$, 
$58 \%$, and $72 \%$. Authors also pointed out that the use of wheat straw in greater proportion provided improvement in water resistance of produced panels. This result is related to the greater silica content in this material and to the geometry of the particles. Compared to populus, wheat straw particles are longer and thinner. The values obtained by these authors are lower than those of this study for the mechanical properties are and higher for the physical properties of the panels. The improvement in water resistance coupled with the particle dimensions was also evidenced for the thickness swelling property for panels produced with the mixture of Populus deltoides and Pinus taeda in both ages.
Nourbakhsh (2010) used wood particles of Populus deltoides with 3 years of age and urea-formaldehyde resin in the proportion of $10 \%$ in the production of MDP panels with a density of $0.70 \mathrm{~g}^{\mathrm{cm}} \mathrm{cm}^{-3}$. For mechanical properties, values of $16.81 \mathrm{MPa}, 1890 \mathrm{MPa}$, and $0.86 \mathrm{MPa}$, for MOR, MOE, and IB were obtained, while for physical properties of thickness swelling after 2 and 24 hours of immersion, $19.07 \%$ and $21.84 \%$ were obtained. Results obtained by the author are close to this study (Table 4), confirming the feasibility of Populus deltoides wood in the early years for non-structural uses as interior decoration (furniture, walls, and ceiling).

Table 4. Physical-mechanical properties of MDP panels.

\begin{tabular}{|c|c|c|c|c|c|c|c|c|c|c|}
\hline \multirow{2}{*}{ Panel } & \multirow{2}{*}{$\begin{array}{c}\mathrm{Cd} \\
\left(\mathrm{g} \cdot \mathrm{cm}^{-3}\right)\end{array}$} & \multirow{2}{*}{$\begin{array}{c}\text { Pd } \\
\left(\mathrm{g} \cdot \mathrm{cm}^{-3}\right)\end{array}$} & \multirow{2}{*}{ CR } & \multicolumn{2}{|c|}{ Water absortion } & \multicolumn{2}{|c|}{ Thickness swelling } & \multicolumn{2}{|c|}{ Static bending } & \multirow{2}{*}{$\begin{array}{c}\begin{array}{c}\text { Perpendicular } \\
\text { tensile }\end{array} \\
\begin{array}{c}\text { IB } \\
(\mathrm{MPa})\end{array}\end{array}$} \\
\hline & & & & $\begin{array}{l}\text { WA2 } \\
(\%)\end{array}$ & $\begin{array}{c}\text { WA24 } \\
(\%)\end{array}$ & $\begin{array}{l}\text { TS2 } \\
(\%)\end{array}$ & $\begin{array}{c}\text { TS24 } \\
(\%)\end{array}$ & $\begin{array}{l}\text { MOR } \\
(\mathrm{MPa})\end{array}$ & $\begin{array}{l}\text { MOE } \\
(\mathrm{MPa})\end{array}$ & \\
\hline $100 \% \mathrm{Pt}$ & 0.41 & $\begin{array}{l}0.66 \mathrm{a} \\
(3.73)\end{array}$ & $\begin{array}{c}1.62 \mathrm{ab} \\
(3.73)\end{array}$ & $\begin{array}{l}28.63 \mathrm{a} \\
(17.40)\end{array}$ & $\begin{array}{l}71.29 \mathrm{a} \\
(10.60)\end{array}$ & $\begin{array}{c}13.55 \mathrm{~b} \\
(9.14)\end{array}$ & $\begin{array}{l}32.49 \mathrm{a} \\
(10.26)\end{array}$ & $\begin{array}{l}18.23 \mathrm{a} \\
(16.88)\end{array}$ & $\begin{array}{c}2112.33 \mathrm{ab} \\
(15.27)\end{array}$ & $\begin{array}{c}0.62 \mathrm{~b} \\
(10.25)\end{array}$ \\
\hline $100 \% \operatorname{Pd} 8$ & 0.38 & $\begin{array}{l}0.65 \mathrm{a} \\
(4.01)\end{array}$ & $\begin{array}{l}1.67 \mathrm{a} \\
(4.01)\end{array}$ & $\begin{array}{l}17.52 \mathrm{c} \\
(19.55)\end{array}$ & $\begin{array}{l}49.14 \mathrm{c} \\
(10.84)\end{array}$ & $\begin{array}{l}12.26 \mathrm{~b} \\
(10.91)\end{array}$ & $\begin{array}{c}34.72 \mathrm{a} \\
(7.84)\end{array}$ & $\begin{array}{l}17.80 \mathrm{a} \\
(12.56)\end{array}$ & $\begin{array}{c}2267.53 \mathrm{a} \\
(13.99)\end{array}$ & $\begin{array}{l}0.75 \mathrm{a} \\
(9.18)\end{array}$ \\
\hline $\begin{array}{l}50 \% \mathrm{Pt}+ \\
50 \% \mathrm{Pd} 8\end{array}$ & 0.40 & $\begin{array}{l}0.64 \mathrm{a} \\
(3.88)\end{array}$ & $\begin{array}{l}1.60 \mathrm{~b} \\
(3.88)\end{array}$ & $\begin{array}{c}24.76 \mathrm{ab} \\
(19.87)\end{array}$ & $\begin{array}{c}75.13 \mathrm{a} \\
(8.80)\end{array}$ & $\begin{array}{c}9.39 c \\
(13.67)\end{array}$ & $\begin{array}{l}27.78 \mathrm{~b} \\
(14.03)\end{array}$ & $\begin{array}{l}13.13 \mathrm{~b} \\
(11.89)\end{array}$ & $\begin{array}{c}1833.54 \mathrm{~b} \\
(8.62)\end{array}$ & $\begin{array}{c}0.54 \mathrm{c} \\
(12.21)\end{array}$ \\
\hline $100 \% \operatorname{Pd} 12$ & 0.40 & $\begin{array}{l}0.65 \mathrm{a} \\
(3.55)\end{array}$ & $\begin{array}{l}1.54 \mathrm{c} \\
(3.55)\end{array}$ & $\begin{array}{l}22.99 \mathrm{~b} \\
(13.03)\end{array}$ & $\begin{array}{c}70.69 a \\
(8.52)\end{array}$ & $\begin{array}{l}15.49 \mathrm{a} \\
(10.18)\end{array}$ & $\begin{array}{l}34.22 \mathrm{a} \\
(13.92)\end{array}$ & $\begin{array}{l}13.98 \mathrm{~b} \\
(19.87)\end{array}$ & $\begin{array}{c}2259.11 \mathrm{a} \\
(16.37)\end{array}$ & $\begin{array}{c}0.55 \mathrm{c} \\
(13.76)\end{array}$ \\
\hline $\begin{array}{c}50 \% \mathrm{Pt}+ \\
50 \% \mathrm{Pd} 12\end{array}$ & 0.41 & $\begin{array}{l}0.64 \mathrm{a} \\
(4.21)\end{array}$ & $\begin{array}{l}1.55 \mathrm{c} \\
(4.21)\end{array}$ & $\begin{array}{c}25.23 \mathrm{ab} \\
(14.39)\end{array}$ & $\begin{array}{l}63.19 \mathrm{~b} \\
(11.77)\end{array}$ & $\begin{array}{l}10.17 \mathrm{c} \\
(10.52)\end{array}$ & $\begin{array}{c}31.25 \mathrm{ab} \\
(13.40)\end{array}$ & $\begin{array}{l}12.78 \mathrm{~b} \\
(16.46)\end{array}$ & $\begin{array}{c}2216.53 \mathrm{a} \\
(22.58)\end{array}$ & $\begin{array}{c}0.52 \mathrm{c} \\
(13.13)\end{array}$ \\
\hline
\end{tabular}

Legend: Pt - Pinus taeda; Pd8 - Populus deltoides 8 years; Pd12 - Populus deltoides 12 years; Cd - composition density; Pd - panel density; CR - compression ratio; WA2 - water absorption after 2 hours of immersion; WA24 - water absorption after 24 hours of immersion; TS2 - thickness swelling after 2 hours of immersion; TS24 - thickness swelling after 24 hours of immersion; MOR - modulus of rupture; MOE - modulus of elasticity; IB - internal bond; averages followed by the same letter in the column do not differ by Tukey test at $5 \%$ probability of error; value in parentheses refers to the percentage variation coefficient.

As shown in Table 5, the HDP panels presented a density close to the nominal density established at $0.90 \mathrm{~g} . \mathrm{cm}^{-3}$, being classified according to the criteria of the ANSI A208.1 standard (ANSI, 2009) as high density (>0.80 g.cm $\left.{ }^{-3}\right)$.

For other properties analyzed shown in Table 5, a statistical significant difference was found. It is noteworthy that panels made with Populus deltoides wood in both ages, pure or mixed with Pinus taeda, presented lower average values than the Pinus taeda panels for water absorption and thickness swelling after 2 and 24 hours of immersion and, higher average values for MOR, MOE and IB.

There's no Brazilian normative standards for highdensity particleboard (HDP), therefore, obtained results were compared to values established by the American standard ANSI A208.1 (ANSI, 2009). This standard establishes values for MOR, MOE and IB of $14.9 \mathrm{MPa}, 2160 \mathrm{MPa}$ and 0.81
$\mathrm{MPa}$, respectively. In this case, only HDP panels produced with Populus deltoides at both ages (8 and 12 years), met the minimum requirement for IB.

The improvement of physical and mechanical properties of the MDP and HDP panels linked to the use of Populus deltoides wood may be attributed to the combination of several factors, such as chemical composition, particle geometry, and composition density.

The use of short and thick particles obtained for the wood of Populus deltoides at ages 8 and 12 in the manufacture of the panels, provided the achievement of greater tensile strength perpendicular for the MDP and HDP panels. Pereira et al. (2017) observed a similar behavior for MDP panels produced with industrial particles of Pinus spp and particles of Eucalyptus badjensis produced under laboratory conditions with wood from the entire shaft. 
Table 5. Physical and mechanical properties of HDP panels.

\begin{tabular}{|c|c|c|c|c|c|c|c|c|c|c|}
\hline \multirow{2}{*}{ Panel } & \multirow{2}{*}{$\begin{array}{c}\mathrm{Cd} \\
\left(\mathrm{g} \cdot \mathrm{cm}^{-3}\right)\end{array}$} & \multirow{2}{*}{$\begin{array}{c}\text { Pd } \\
\left(\text { g.cm }{ }^{-3}\right)\end{array}$} & \multirow{2}{*}{ CR } & \multicolumn{2}{|c|}{ Water absortion } & \multicolumn{2}{|c|}{$\begin{array}{l}\text { Thickness } \\
\text { swelling }\end{array}$} & \multicolumn{2}{|c|}{ Static bending } & \multirow{2}{*}{$\begin{array}{c}\begin{array}{c}\text { Perpendicular } \\
\text { tensile }\end{array} \\
\text { IB } \\
(\mathrm{MPa})\end{array}$} \\
\hline & & & & $\begin{array}{l}\text { WA2 } \\
(\%)\end{array}$ & $\begin{array}{c}\text { WA24 } \\
(\%)\end{array}$ & $\begin{array}{l}\text { TS2 } \\
(\%)\end{array}$ & $\begin{array}{c}\text { TS24 } \\
(\%)\end{array}$ & $\begin{array}{l}\text { MOR } \\
(\mathrm{MPa})\end{array}$ & $\begin{array}{l}\text { MOE } \\
(\mathrm{MPa})\end{array}$ & \\
\hline $100 \% \mathrm{Pt}$ & 0.41 & $\begin{array}{l}0.91 \mathrm{a} \\
(3.56)\end{array}$ & $\begin{array}{l}2.21 \mathrm{c} \\
(3.56)\end{array}$ & $\begin{array}{l}27.92 \mathrm{a} \\
(20.68)\end{array}$ & $\begin{array}{c}62.41 \mathrm{a} \\
(8.73)\end{array}$ & $\begin{array}{l}11.60 \mathrm{a} \\
(19.04)\end{array}$ & $\begin{array}{l}30.87 \mathrm{a} \\
(10.99)\end{array}$ & $\begin{array}{c}22.84 \mathrm{ab} \\
(10.90)\end{array}$ & $\begin{array}{c}2574.57 \mathrm{~b} \\
(12.04)\end{array}$ & $\begin{array}{c}0.66 \mathrm{~b} \\
(11.51)\end{array}$ \\
\hline $100 \% \operatorname{Pd} 8$ & 0.39 & $\begin{array}{l}0.93 \mathrm{a} \\
(3.58)\end{array}$ & $\begin{array}{l}2.39 \mathrm{a} \\
(3.58)\end{array}$ & $\begin{array}{l}16.70 \mathrm{~b} \\
(21.00)\end{array}$ & $\begin{array}{l}43.76 \mathrm{~b} \\
(17.58)\end{array}$ & $\begin{array}{l}9.65 \mathrm{bc} \\
(11.11)\end{array}$ & $\begin{array}{c}27.86 \mathrm{ab} \\
(18.45)\end{array}$ & $\begin{array}{c}25.67 \mathrm{a} \\
(7.76)\end{array}$ & $\begin{array}{c}3150.31 \mathrm{a} \\
(8.66)\end{array}$ & $\begin{array}{c}0.82 \mathrm{a} \\
(10.92)\end{array}$ \\
\hline $\begin{array}{c}50 \% \mathrm{Pt}+50 \% \\
\mathrm{Pd} 8\end{array}$ & 0.40 & $\begin{array}{l}0.93 \mathrm{a} \\
(3.43)\end{array}$ & $\begin{array}{l}2.32 \mathrm{~b} \\
(3.43)\end{array}$ & $\begin{array}{l}20.47 \mathrm{~b} \\
(25.63)\end{array}$ & $\begin{array}{l}48.42 \mathrm{~b} \\
(10.88)\end{array}$ & $\begin{array}{l}7.98 \mathrm{~cd} \\
(18.43)\end{array}$ & $\begin{array}{c}27.48 \mathrm{ab} \\
(14.25)\end{array}$ & $\begin{array}{l}21.33 \mathrm{~b} \\
(10.41)\end{array}$ & $\begin{array}{c}2988.37 \mathrm{ab} \\
(9.81)\end{array}$ & $\begin{array}{l}0.62 \mathrm{~b} \\
(14.37)\end{array}$ \\
\hline $100 \% \operatorname{Pd} 12$ & 0.42 & $\begin{array}{l}0.94 \mathrm{a} \\
(2.43)\end{array}$ & $\begin{array}{l}2.24 \mathrm{c} \\
(2.43)\end{array}$ & $\begin{array}{l}18.32 \mathrm{~b} \\
(16.94)\end{array}$ & $\begin{array}{l}46.06 \mathrm{~b} \\
(14.05)\end{array}$ & $\begin{array}{c}10.20 \mathrm{ab} \\
(12.90)\end{array}$ & $\begin{array}{c}27.23 \mathrm{ab} \\
(16.89)\end{array}$ & $\begin{array}{c}23.05 \mathrm{ab} \\
(11.69)\end{array}$ & $\begin{array}{c}2840.14 \mathrm{ab} \\
(12.09)\end{array}$ & $\begin{array}{l}0.82 \mathrm{a} \\
(9.96)\end{array}$ \\
\hline $\begin{array}{c}50 \% \mathrm{Pt}+50 \% \\
\mathrm{Pd} 12\end{array}$ & 0.42 & $\begin{array}{l}0.93 \mathrm{a} \\
(2.43)\end{array}$ & $\begin{array}{l}2.24 \mathrm{c} \\
(2.43)\end{array}$ & $\begin{array}{l}19.61 \mathrm{~b} \\
(19.52)\end{array}$ & $\begin{array}{l}46.47 \mathrm{~b} \\
(14.65)\end{array}$ & $\begin{array}{l}6.87 \mathrm{~d} \\
(12.08)\end{array}$ & $\begin{array}{l}25.42 \mathrm{~b} \\
(18.96)\end{array}$ & $\begin{array}{c}23.26 \mathrm{ab} \\
(9.85)\end{array}$ & $\begin{array}{c}2927.36 \mathrm{ab} \\
(13.22)\end{array}$ & $\begin{array}{l}0.68 \mathrm{~b} \\
(11.69)\end{array}$ \\
\hline
\end{tabular}

Legend: Pt - Pinus taeda; Pd8 - Populus deltoides 8 years; Pd12 - Populus deltoids 12 years; Cd - composition density; Pd - panel density; CR - compression ratio; WA2 - water absorption after 2 hours of immersion; WA24 - water absorption after 24 hours of immersion; TS2 - thickness swelling after 2 hours of immersion; TS24 - thickness swelling after 24 hours of immersion; MOR - modulus of rupture; MOE - modulus of elasticity; IB - internal bond; averages followed by the same letter in the column do not differ by Tukey test at $5 \%$ probability of error; value in parentheses refers to the percentage variation coefficient.

Table 6 displays significant positive correlations. In this case, it may be seen the influence of density of composition and compaction ratio under modulus of rupture to static bending and tensile strength perpendicular of MDP properties. It confirmes what was reported by Moslemi (1974), that particleboards produced with low density wood result in better compaction, and consequently, it improve mechanical properties.

The greater compaction rate and better bonding of the MDP particle provided the panels less hygroscopicity. It is observed a significant negative correlation between compaction ration and water absorption after 24 hours of immersion, and internal bond and water absorption after 2 and 24 hours of immersion. According to Frihart and Hunt (2010) and Trianoski et al. (2013), this behavior may be related to the wood chemical composition, mainly the presence of extracts. The presence of extractives may interfere in a physical way in the bonding process, as forming a barrier on the surface through its migration during the wood drying process, as well as in a chemical way, depending on the nature of the extracts they may be more acidic, interfering in the cure of the resin.

Significant positive and negative correlations were obtained for physical properties such as water absorption and thickness swelling of the MDP, in addition to a significant positive correlation between the modulus of rupture in static bending and internal bond. There is a significant positive correlation between thickness swelling and modulus of elasticity in static bending, which may be attributed to the swelling of the wood itself, the return in thickness of the panel after pressing and material separation (Hsu, 1987).

For HDP, Pearson's correlations between physical and mechanical properties are in Table 7. It is noteworthy a significant positive correlation between the compaction ratio and the modulus of elasticity in static bending, and between water absorption and thickness swelling. In addition to significant negative correlation between water absorption after 2 hours of immersion and modulus of elasticity in static bending.

Table 6. Pearson correlation between the physical and mechanical properties obtained for the MDP panels.

$\begin{array}{lccccccccc} & \text { Pd } & \text { CR } & \text { WA2 } & \text { WA24 } & \text { TS2 } & \text { TS24 } & \text { MOR } & \text { MOE } & \text { IB } \\ \text { Pd } & 1 & 0.452 & -0.054 & -0.232 & 0.340 & 0.239 & 0.529^{*} & 0.330 & 0.206 \\ \text { CR } & & 1 & -0.426 & -0.524^{*} & -0.168 & 0.054 & 0.599^{*} & -0.060 & 0.718^{*} \\ \text { WA2 } & & & 1 & 0.835^{*} & -0.104 & -0.551^{*} & -0.214 & -0.297 & -0.541^{*} \\ \text { WA24 } & & & 1 & -0.051 & -0.590^{*} & -0.396 & -0.387 & -0.674^{*} \\ \text { TS2 } & & & & 1 & 0.687^{*} & 0.486 & 0.633^{*} & 0.250 \\ \text { TS24 } & & & & & 1 & 0.495 & 0.624^{*} & 0.498 \\ \text { MOR } & & & & & & 1 & 0.400 & 0.779^{*} \\ \text { MOE } & & & & & & & 1 & 0.325 \\ \text { IB } & & & & & & & & & 1\end{array}$

Legend: Pd - panel density; CR - compression ratio; WA2 - water absorption after 2 hours of immersion; WA24 - water absorption after 24 hours of immersion; TS2 - thickness swelling after 2 hours of immersion; TS24 - thickness swelling after 24 hours of immersion; MOR - modulus of rupture; MOE - modulus of elasticity; IB - internal bond; * - significant level of $5 \%$ probability of error.

Table 7. Pearson correlation between the physical and mechanical properties obtained for the HDP panels.

$\begin{array}{llllllll}\text { Pd } & \text { CR } & \text { WA2 } & \text { WA24 } & \text { TS2 } & \text { TS24 } & \text { MOR MOE } & \text { IB }\end{array}$

$\begin{array}{llllllllll}\text { Pd } & 1 & 0.300 & -0.270 & -0.184 & -0.043 & -0.027 & -0.017 & 0.151 & 0.286\end{array}$

$\begin{array}{lllllllll}\text { CR } & 1 & -0.472 & -0.380 & -0.150 & 0.026 & 0.231 & 0.553^{*} & 0.277\end{array}$

$\begin{array}{llllll}\text { WA2 } & 1 & 0.886^{*} & 0.399 & 0.559^{*}-0.376-0.688^{*}-0.225\end{array}$

$\begin{array}{llllll}\text { WA24 } & 1 & 0.563^{*} & 0.747^{*}-0.237-0.487-0.240\end{array}$

$\begin{array}{llllll}\text { TS2 } & 1 & 0.698^{*} & 0.117 & -0.422 & 0.177\end{array}$

$\begin{array}{llllll}\text { TS24 } & 1 & -0.024 & -0.248 & 0.005\end{array}$

$\begin{array}{lllll}\text { MOR } & 1 & 0.371 & 0.227\end{array}$

$\begin{array}{lll}\text { MOE } & 1 & 0.076\end{array}$

\section{IB} 1

Legend: Pd - panel density; $\mathrm{CR}$ - compression ratio; WA2 - water absorption after 2 hours of immersion; WA24 - water absorption after 24 hours of immersion; TS2 - thickness swelling after 2 hours of immersion; TS24 - thickness swelling after 24 hours of immersion; MOR - modulus of rupture; MOE - modulus of elasticity; IB - internal bond; ${ }^{*}$ - significant level of $5 \%$ probability of error. 


\section{CONCLUSIONS}

The wood of Populus deltoides with 8 and 12 years old presented basic density close to the wood of Pinus taeda, a species traditionally used in the manufacture of particulate panels.

The use of short and thick particles of Populus deltoides in the production of MDP and HDP panels, resulted in better tensile strength perpendicular, and when mixed the long and fine particles of Pinus taeda improved the dimensional stability of the panels, mainly for the thickness swelling property.

The mechanical properties obtained met the minimum requirements established by the NBR 14810-2 standard for non-structural medium density particulate panels intended for internal use and, ANSI A208.1 for high-density particulate panels.

Pearson's correlations obtained for the MDP and HDP panels demonstrated that the use of low-density wood together with the compaction and bonding of the panel positively influenced the physical-mechanical properties, and that the dimensional stability of the panel had an influence mainly on the modulus of elasticity to static bending.

In view of the results obtained for the physical and mechanical properties evaluated for wood or panels, it is recommended to use Populus deltoides at 8 years, pure or mixed with Pinus taeda in the manufacture of medium and high-density particulate panels, enabling the conduction of plantings of this species for this purpose in a short rotation system.

\section{SUBMISSION STATUS}

Received: 12 Nov. 2020

Accepted: 21 Jul. 2021

Associate editor: Geraldo Bortoletto Junior (1)

\section{CORRESPONDENCE TO}

\section{Pâmela Caroline Lau Sozim}

Universidade Estadual do Centro-Oeste, Programa de Pós-Graduação em Ciências Florestais, Rua Professora Maria Roza Zanon de Almeida, Engenheiro Gutierrez, 84505-677, Irati, PR, Brasil.

e-mail: pamela.lau@hotmail.com

\section{REFERENCES}

American National Standards Institute. ANSI A208.1: mat-formed wood particleboard - specifications. Gaithersburg; 2009.

Arauco Forest Brasil SA. Resumo público do manejo florestal: regiões de Campo do Tenente e Sengés. 2018.

Arce JE. Modelagem da estrutura de florestas clonais de Populus deltoides Marsh. através de distribuições diamétricas probabilísticas. Ciência Florestal 2004; 14(1): 149-164.
Associação Brasileira de Normas Técnicas. NBR 11941: madeira determinação da densidade básica. Rio de Janeiro; 2003.

Associação Brasileira de Normas Técnicas. NBR 14853: madeira - determinação do material solúvel em etanol: tolueno e em diclorometano. São Paulo; 2002.

Associação Brasileira de Normas Técnicas. NBR 14810-2: chapas de madeira aglomerada - parte 2 - requisitos. Rio Janeiro; 2013.

Benites PKRM, Lopes AS, Gouvêa AFG, Silva FC, Souza CCB. Caracterização tecnológica da madeira de híbridos de eucalipto irrigados e fertirrigados. Ciência Florestal 2018; 28 (4): 1716-1728.

Berneck SA. Resumo público 2019: Gilson Mueller Berneck e Florestal Segundo Planalto; 2019.

Bianche JJ, Carneiro ACO, Vital BR, Pereira FA, Santos RC, Soratto DN. Propriedades de painéis aglomerados fabricados com partículas de eucalipto (Eucalyptus urophylla), paricá (Schizolobium amazonicum) e vassoura (Sida spp.). Cerne 2012; 18 (4): 623-630.

Borodowski ED. Álamos y sauces en el Delta del Paraná: situación del sector y silvicultura. Actas Jornadas de Salicáceas 2006; 61-70.

Carneiro ACO, Castro AFN, Castro RVO, Santos RC, Ferreira LP, Damásio RAP et al. Potencial energético da madeira de Eucalyptus sp. em função da idade e de diferentes materiais genéticos. Árvore 2014; 38 (2): 375-381.

Fonte APN, Trianoski R, Iwakiri S, Anjos RAM. Propriedades físicas e químicas da madeira de cerne e alburno de Cryptomeria japonica. Revista de Ciências Agroveterinárias 2017; 16(3): 277-285.

Forest Stewardship Council (FSC). Public certificate search. [cited 2020 feb. 19]. Available from: https://info.fsc.org/certificate. php?lang=POR.

Frihart CR, Hunt CG. Adhesives with wood materials: bond formation and performance. In: Forest Products Laboratory. Wood Handbook - Wood as an engineering material. Ed. Centenária. Madison: USDA; 2010.

Garcia EA, Guerra SPS, Eufrade Junior HJ, Sansígolo A, Lanças KP, Yamaji F M. Análise química da madeira com casca em sistemas florestais de curta rotação. Árvore 2016; 40 (1): 163-171.

Hafezi SM, Enayati A, Hosseini KD, Tarmian A, Mirshokraii SA. Use of amino silane coupling agent to improve physical and mechanical properties of UF-bonded wheat straw (Triticum aestivum L.) poplar wood particleboard. Journal of Forestry Research 2015.

Hsu QE. A process for stabilizing waferboard/OSB. In: Proceedings of the Washington State University. Particleboard Symposium 21, Washington; 1987.

Iwakiri S, Zeller F, Pinto JÁ, Ramirez MGL, Souza MM, Seixas R. Avaliação do potencial de utilização da madeira de Schizolobium amazonicum "Paricá" e Cecropia hololeuca "Embaúba" para produção de painéis aglomerados. Acta amazonica 2010; 40(2): 303-308.

Iwakiri S, Trianoski R, Chies D, Tavares EL, França MC, Lau PC et al. Use of residues of forestry exploration of Pinus taeda for particleboard manufacture. Árvore 2017; 41(3).

Iwakiri S, Trianoski R, Raia RZ, Keinert AC, Paula CRP, Protzek GR et al. Produção de painéis aglomerados de Hevea brasiliensis (Clone RRIM 600) em mistura com três espécies de Eucalyptus 
utilizadas pelas indústrias de São Paulo. Scientia Forestalis 2018; 46(117): 31-39.

Iwakiri S, Trianoski R, Silva AL, Stüpp AM, Cabral BM, Vieira HC. Evaluatiom of physical and mechanical properties of particleboard produced from wood of Cupressus torulosa in mixture with Pinus taeda. Floresta 2020; 50(3): 1478-1485.

Javarini E. Caracterização das propriedades físicas e mecânicas de Populus deltoides, plantado nas várzeas do Vale Médio do Rio Iguaçu [trabalho de conclusão de curso]. União da Vitória, Centro Universitário de União da Vitória; 2011.

Jin XJ, Kamdem DP. Chemical composition, crystallinity and crystallite cellulose size in Populus hybrids and aspen. Cellulose Chemical Technology 2009; 43 (7-8): 229-234.

Klasnja B, Kopitovic S, Orlovic S. Variability of some wood properties of eastern cottonwood (Populus deltoides Bartr.) clones. Wood Science Technology 2003; 37: 331-337.

Kuzovkina YA, Vietto L. An update on the cultivar registration of Populus and Salix (Salicaceae). Skvortsovia 2014; 1(2): 133-148.

Lau, PC. Produção de painéis de colagem lateral - EGP com madeira de Populus deltoides [dissertação]. Curitiba: Setor de Ciências Agrárias, Universidade Federal do Paraná; 2017.

Lorenzi H, Souza HM, Torres MAV, Bacher LB. Árvores exóticas no Brasil. Nova Odessa: Instituto Plantarum; 2003.

Medeiros JGS, Hoppe JM. Efeito da aplicação de calcário em estacas de Populus deltoides Bartr. ex Marsh cultivadas em vaso. Ciência Florestal 2002; 12 (2), 161-167.

Moslemi AA. Particleboard: volume 1 - Materials. London: Southern Illinois University Press; 1974.

Nourbakhsh, A. Mechanical and Thickness Swelling of Particleboard Composites Made from Three-Year-Old Poplar Clones. Journal of Reinforced Plastics and Composites 2010; 29(4).

Pereira GF, Rios PD, Buss R, Vieira HC, Grubert W, Cunha AB et al. Painéis de madeira aglomerada de Eucalyptus badjensis e Pinus spp. Scientia Forestalis 2017; 45(114): 373-382.

Rios PD, Pereira GF, Vieira HC, Grubert W, Cunha AB, Brand MA. Avaliação do potencial da madeira de Pinus patula Schltdl. \& Cham para a produção de painéis de madeira aglomerada. Scientia Forestalis 2016; 44(110): 497-508.

Sanches FL, Hillig E, Iwakiri S, Napoli LM. Resistência de painéis aglomerados produzidos com mistura de madeira de espécies florestais tradicionais e não tradicionais. Ciência Florestal 2016; 26(2): 559-569.

Soares VC, Bianchi ML, Trugilho PF, Höfler J, Pereira AJ. Análise das propriedades da madeira e do carvão vegetal de híbridos de eucalipto em três idades. Cerne 2015; 21(2): 191-197.
Sozim PCL, Napoli LM, Ferro FS, Mustefaga EC, Hillig E. Propriedades de painéis aglomerados produzidos com madeiras de Ligustrum lucidum e Pinus taeda. Pesquisa Florestal Brasileira 2019; 39: 1-8.

Sociedade Brasileira de Silvicultura (SBS). Fatos e números do Brasil florestal. São Paulo; 2006.

Technical Association of the Pulp and Paper Industry. TAPPI 204cm97: solvent extractives of wood and pulp. Atlanta; 1997.

Technical Association of the Pulp and Paper Industry.. TAPPI 207 cm-99: water solubility of wood and pulp. Atlanta; 1999.

Technical Association of the Pulp and Paper Industry. TAPPI 211 om-02: ash in wood, pulp, paper and paperboard - combustion at $525^{\circ} \mathrm{C}$. Atlanta; 2002.

Technical Association of the Pulp and Paper Industry. TAPPI 212 om-02: one percent sodium hydroxide solubility of wood and pulp. Atlanta; 2002

Technical Association of the Pulp and Paper Industry. TAPPI 222 om-02: acid-insoluble lignin in wood and pulp. Atlanta; 2002.

Technical Association of the Pulp and Paper Industry. TAPPI 252 om-02: $\mathrm{pH}$ and electrical conductivity of hot water extracts of pulp, paper, and paperboard. Atlanta; 2002.

Trianoski R, Iwakiri S, Matos JLM, Prata JG. Viabilidade da utilização de Acrocarpus fraxinifolius em diferentes proporções com Pinus spp. para produção de painéis aglomerados. Scientia Forestalis 2011; 39 (91): 343-350.

Trianoski R, Iwakiri S, Matos JLM, Chies D. Utilização da madeira de Cryptomeria japonica para produção de painéis aglomerados. Scientia Forestalis 2013; 41(97): 57-64.

Trianoski R, Iwakiri S, Matos, JL. Avaliação de painéis aglomerados de Toona ciliata produzidos com diferentes densidades e teores de resina. Madera y Bosques 2014; 20 (3): 49 - 58.

Trianoski R, Piccardi ABR, Iwakiri S, Matos JLM, Bonduelle GM. Incorporação de Grevillea robusta na produção de painéis aglomerados de Pinus. Floresta 2016; 46(2): 259-267.

Trianoski R, Iwakiri S, Machado L, Rosa TS. Feasibility of Cordia trichotoma (Vell.) wood and its by-products for particleboard manufacturing. Journal of Sustainable Forestry 2017; 1-14.

Vidaurre GB, Carneiro ACO, Vital BR, Santos RC, Valle MLA. Propriedades energéticas da madeira e do carvão de paricá (Schizolobium amazonicum). Árvore 2012; 36(2): 365-371.

VitaL BR, Haselein CR, Della Lucia RM. Efeito da geometria das partículas nas propriedades das chapas de madeira aglomerada de Eucalyptus grandis (Hill ex-Maiden). Árvore 1992; 16(1): 88-96. 